\title{
Concepts for the sustainable management of multi-scale flow systems: the groundwater system within the Laufen Basin, Switzerland
}

\author{
Peter Huggenberger · Jannis Epting • \\ Stefan Scheidler
}

Received: 30 August 2012/Accepted: 2 February 2013/Published online: 21 February 2013

(c) Springer-Verlag Berlin Heidelberg 2013

\begin{abstract}
Many groundwater systems consist of multiscale aquifer units. The exchange processes and rates between these aquifer units are complex. In order to manage such complex systems, a subdivision into different catchments, sub-catchments or groundwater bodies as manageable units is required. The sustainable management of water resources requires a comprehensive view of waterquality and water-quantity aspects not only for water supply issues, but generally also for flood protection and riverine ecosystem functions. Such transformations require an improved understanding of recharge and exchange processes between different aquifer units as well as aquifersurface water interaction-processes at different spatiotemporal scales. The main objective of this study is to illustrate concepts by defining the geometry and scales of different aquifer units within a sedimentary basin. The Laufen Basin in the Jura Mountains represents a sub-catchment of the River Birs (Switzerland). Its structure is characterized by a pronounced local relief and a series of aquifer units which are typical for many complex groundwater systems in front of mountain chains such as the alpine foreland and the Jura Mountains of Central Europe. A combination of different concepts is required to understand multi-scale flow systems and to describe the various hydrogeological processes. Three concepts are proposed for the Laufen Basin, including: (1) a regional flow-system analysis, based on the concept of hierarchical groundwater flow systems; (2) the
\end{abstract}

\footnotetext{
P. Huggenberger $(\bowtie) \cdot J$. Epting $\cdot$ S. Scheidler

Department of Environmental Sciences,

Applied and Environmental Geology, University of Basel,

Bernoullistr. 32, 4056 Basel, Switzerland

e-mail: peter.huggenberger@unibas.ch

J. Epting

e-mail: jannis.epting@unibas.ch
}

river-corridor concept for understanding aquifer-surface water interaction processes; and (3) the calculation of the dynamic vulnerability index and the aquifer base gradient approach for karst flow and fractured flow systems.

Keywords Multi-scale flow systems - Groundwater body · River-groundwater interaction - Aquifer base gradient . Dynamic vulnerability · Laufen Basin

\section{Introduction}

In the last decade, water resources management and in particular groundwater protection has been directed towards resource management within catchments or sub-catchments (Wasser-Agenda 2011). Specific groundwater protection or management measures require fundamental knowledge at the process relevant scales. Therefore, anthropogenic changes such as land-use changes as a consequence of increasing urbanization, agricultural development, the corresponding increasing pressure on water resources (industrial- and old waste sites, storm-water management in populated areas, flood protection, ecological aspects of riverine landscapes and the consequences of climate change) (BAFU 2012) need to be considered at the catchment or groundwater body scale.

The different anthropogenic changes include quantitative as well as qualitative effects on groundwater. Especially local and regional scale management policies could influence the success of mitigation strategies for groundwater shortage or extreme flood events. However, in practice, for most groundwater systems it is not clear how to develop groundwater management strategies that bring together the different interests of groundwater use and the complexity of processes acting at the regional scale. 
According to Seward et al. (2006) groundwater sustainability is not equal to annual (natural or anthropogenic) recharge. The authors show that the interaction between different flow systems, surface-groundwater interactions and anthropogenic influences have to be integrated (Bencala 1993; Kalbacher et al. 2012; Grathwohl et al. 2012). Furthermore, the authors conclude that there is no single "safe" or "sustainable" yield for a groundwater basin, but rather a range of "permissible" yields dependent on how the groundwater is accessed for social, economic, and ecological aspects. The scientific debate (Wiering and Immink 2006) on the management of water resources on the catchment scale includes addressing the influence of anthropogenic impacts on the quality and quantity of groundwater resources. Each groundwater flow system exhibits specific residence time distributions (Maxwell and Kollet 2008) and therefore, the memory effect of anthropogenic activities (i.e. groundwater pollution, concentrations of pesticides) or effects of climate change might not be depicted by groundwater monitoring systems without understanding the scales and interactions between the different aquifer units (Epting and Huggenberger submitted-b, a). Thus, the focus of catchment or sub-catchment scale groundwater research is on improving the understanding of the relevant hydrologic-hydrogeologic processes acting in catchments or sub-catchments.

Many areas in Central Europe are characterized by complex landforms and geological settings that produce multi-scale groundwater flow systems (Tóth 1963b). The European Water Framework Directives (WFD) outlines new concepts for the sustainable use of water resources that define river catchments as manageable units with the goal to protect, enhance and restore bodies of groundwater (CEC 2000). The WFD introduced the notion of specific River Basin Districts (RBD) and a new definition of a body of groundwater (GWB)- "a GWB is a distinct volume of groundwater within an aquifer or aquifers". According to the WFD, a GWB is a management unit of groundwater necessary for a subdivision of aquifers in order for them to be effectively managed. In the same context, the terms sub-catchment and aquifer units are used to describe the subdivision of large catchments that differ from other units of the same catchment with respect to geology or hydrological and hydrogeological processes, but which are generally larger than GWBs.

This contribution is based on the experience gained from different projects in a small intramontane sedimentary basin within the Jura mountain chain south of Basel (Switzerland). The existence of several aquifer units at different spatiotemporal scales complicates the integration of different management aspects (industrial- and old waste sites, storm-water management in populated areas, flood protection, ecological aspects of riverine landscapes and the consequences of climate change), requiring further subdivision. Within the investigated groundwater system, the main aquifers include the: (1) regional and local scale karst aquifer; (2) intermediate regional scale aquifer within the Rhine Graben Molasses; and (3) aquifers within the unconsolidated gravel deposits of the main valleys related to the hyporheic corridor. The integration of relevant hydrogeological processes across the different scales is required (Poole 2002; Ghasemizadeh and Schirmer 2012).

Three concepts for the groundwater system and multiaquifer units of the sedimentary basin are discussed, which allow to describe the characteristic scales and hydrogeologic processes. In particular, the selected concepts are the basis for investigating the dynamics of groundwater flow and quality and the interaction with surface waters in catchments and sub-catchments or groundwater bodies (e.g. Chatterjee et al. 2009). The concepts cover: (1) The investigation of the regional basin or sub-catchment scale by flow-system analysis considering hierarchical groundwater flow systems (Tóth 1962; Zijl 1999); (2) The "river corridor" concept applied to the main valleys as a basis to understand groundwater-surface water interaction processes (Stanford and Ward 1993); and (3) The application of the dynamic vulnerability concept to a local scale karst system (Butscher and Huggenberger 2008, 2009a, b; Butscher et al. 2011a) and the discussion of the aquifer base gradient approach for the regional scale karst- and fractured flow systems (Butscher and Huggenberger 2007). The testing of such concepts on real field situations allows a process-oriented definition of boundaries and to derive fluxes of water and different compounds across boundaries, which are practically unknown at the moment.

The objective of this work is to understand the contribution of the principal flow systems at different scales to the composition of groundwater quality and quantity as well as the composition of the extracted raw water of drinking water production wells especially during high and low flow conditions. Although the present paper concentrates on the discussion of conceptual aspects of multiaquifer flow systems for groundwater management on the catchment scale, it also illustrates some of the processes at different scales that could be relevant for the sustainable management of water resources.

\section{Settings of the Laufen Basin (Switzerland)}

The application of the different concepts is illustrated using the groundwater system and multi-aquifer units of the Laufen Basin. Although many aspects of the system dynamics at different scales are not yet well understood, the occurrence of a large flood event 2007 and several projects which focused on groundwater quality issues 
within the karst and shallow alluvial aquifer systems gave some insight into the complexity of the multi-scale flow systems.

The Laufen Basin is located south of Basel, Switzerland, and represents a sub-catchment of the River Birs (Fig. 1). The total catchment area of the River Birs is $866 \mathrm{~km}^{2}$ and its length $75 \mathrm{~km}$. The altitudes within the entire river catchment range from $763 \mathrm{~m}$ a.s.l. in the headwater regions to $251 \mathrm{~m}$ a.s.l. at the confluence of River Rhine. The Birs mainly flows through the Swiss Jura Mountains. Several small Tertiary basins are embedded within the Jura Mountains (Liniger 1925) forming characteristic sub-catchments, one of these basins is the sub-catchment of Laufen. The subcatchment is populated by more than 20,000 inhabitants and the main land-uses are residential, industrial, agricultural and infrastructure. The water resources of the area are used for agriculture and industry as well as for drinking water production. The waterways are used for storm water discharge.

The Laufen Basin is part of the early Tertiary Rhine Graben system (Laubscher 1998) developed in late Eocene to early Oligocene times (Koch 1923; Bitterli-Brunner and Fischer 1988). The geologic formations of the Laufen Basin comprise mainly Triassic to Quaternary sediments of varying hydraulic conductivities with a gap in the stratigraphic sequence between Early Cretaceous and Early Tertiary units. New palaeogeographical data suggest a possible connection between the southern part of the Rhine Graben and the Bresse Graben and show local drainage directions of fluviatile systems (Picot et al. 2008). The Laufen Basin is bounded to the North and South by two main anticlines, by fault systems to the East and oblique truncated folds to the West. The carbonate formations represent a regional scale karst aquifer, outcropping in the northern and southern edges of the basin (Fig. 2). The underlying Oxfordian marls represent an aquitard which lies above a second regional aquifer of Bathonien age (Hauptrogenstein). The principal regional aquiclude is the Opalinus clay of the Lower Dogger. Morphologically, the carbonate units on the edges represent the recharge area of the basin. The basin is filled with mid- to late-Oligocene deposits (thickness 2-300 m): shales and fluvial sandstones

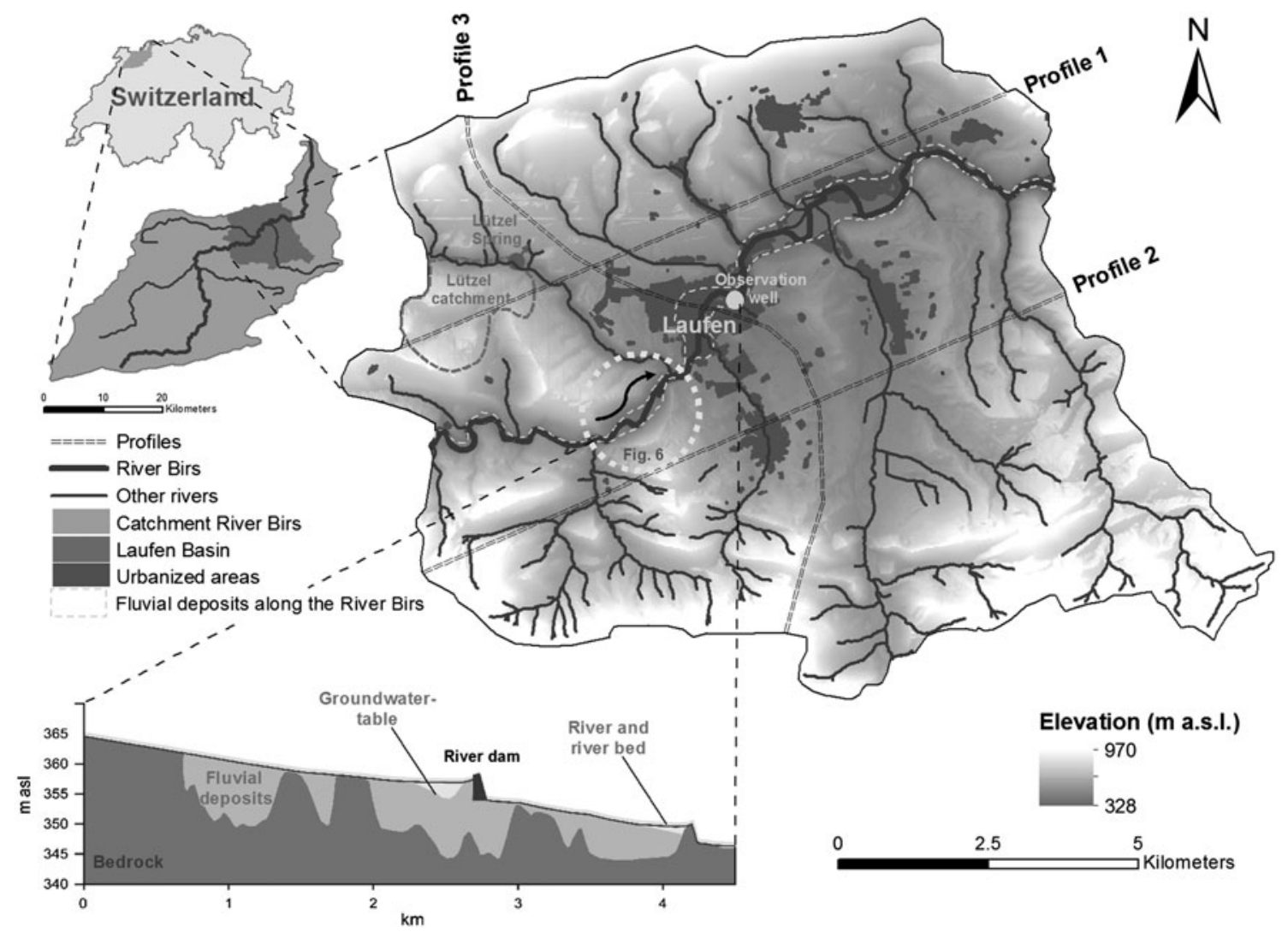

Fig. 1 Location map showing the position of the sub-catchment "Laufen Basin", the River Birs and its tributaries. Elevation is displayed by different grey colors. Profiles 1-3 represent the traces for the flow-system analysis (see Fig. 4); the Lützel catchment represents the locality for the vulnerability study (Fig. 5); the dashed circle shows the location where the interaction of two aquifer units can be observed (see Fig. 6) and the location of one observation well in the city of Laufen is shown (see Fig. 7). Bottom Selected river segment for a longitudinal profile along the river illustrating the bedrock (dark grey) the geometry of valley fills (light grey) in relation to the river bed 
and marls, forming small basins (surface area in the order of $110 \mathrm{~km}^{2}$ ). These in turn are overlain by middle Miocene fluvial deposits (conglomerates, marls and sandstones), with a total thickness in the order of $200 \mathrm{~m}$. During the late Miocene thin-skinned folding phase of the main Jura folds, the Laufen Basin remained practically unfolded. Only on its eastern flanks, some small folds formed in the context of the development of the Rhine Graben System. Later, some reactivation of deep rooted tectonic zones occurred at the two North-South oriented basin sides (Laubscher 1998). Non-consolidated fluvial deposits and colluvium form the youngest geologic units of the basin. Due to the high porosities and permeability, the fluvial gravel forms a productive shallow aquifer within the basin.

\section{Methods}

Flow system analysis and definition of scales

Gravity driven groundwater flow in a sedimentary basin can be thought to be a superposition of several flow systems (Fig. 3). Topography and anisotropy determine the geometry and the penetration of different flow systems.

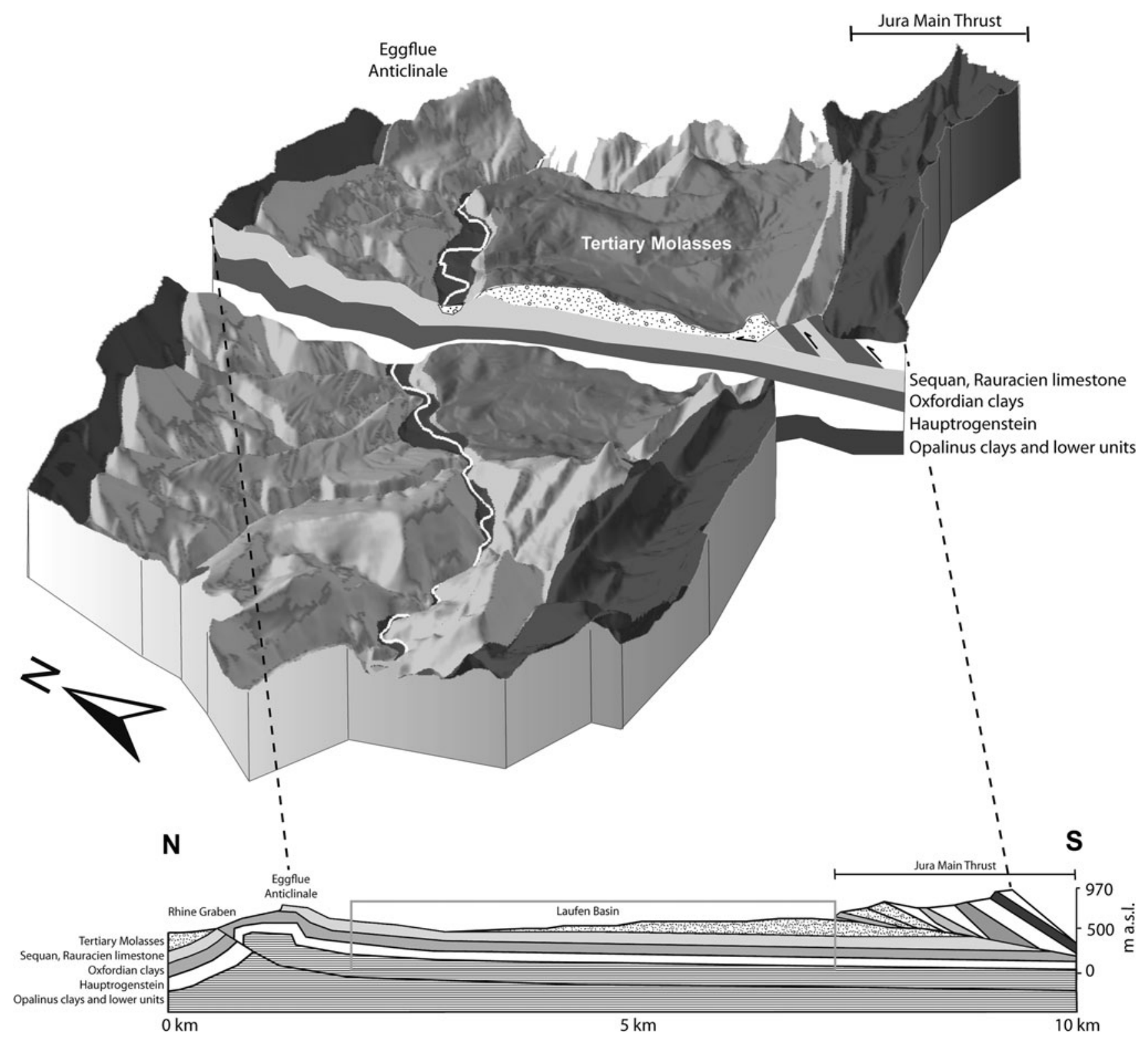

Fig. 2 Conceptual 3D-Model of the Laufen Basin with a simplified illustration of the geological settings, including the main hydrogeological units as well as the Birs valley corridor with unconsolidated Quaternary fluvial deposits. Bottom Geological profile 
Geometry and penetration depth define a hierarchy of the different flow systems (Tóth 2009). The flow-system analysis of hierarchical groundwater flow-systems was originally described by (Tóth 1962, 1963a, 1995, 2009) and later extended by (Zijl 1999) and (Worman et al. 2007; Marklund and Worman 2011). The concept relates the topography of the water table to the topography of the land surface as a primary explanation for the hierarchical nesting of gravity-driven groundwater flow patterns. The flow system concept shows promising results when applied to the analysis of different scales of groundwater flow-systems in topographically and geologically complex areas.

Figure 3a illustrates the different scales of the flow systems within the Laufen Basin by a schematic crosssection. The area includes several main aquifer units and flow systems (Fig. 2): (1) a regional and local scale karst aquifer (karstified limestone of the folded Jura, mainly Upper Oxfordian carbonates and Hauptrogenstein of Bathonien age); (2) an intermediate regional scale aquifer within the Rhine Graben Molasses consisting of Miocene fluvial sandstones and overbank deposits; and (3) aquifers consisting of coarse highly permeable unconsolidated Quaternary gravel deposits.

To analyze topography-driven flow systems, Zijl (1999) made use of Fourier decomposition to separate the different spatial scales of the water table surface. When considering the hierarchy of complex aquifer systems, spectral analysis directly examines the periodicities of the water table by representing the data using a linear combination of harmonics (sinusoidal components) with a range of frequencies. The amplitude of each harmonic determines the relative contribution of that frequency component to the entire water table geometry. The penetration depth $\delta$ of the different systems can be estimated based on a relation given by Zijl (1999):

$\delta=\lambda\left(K_{V} / K_{h}\right)^{1 / 2}$,

where, $\lambda$ are the wavelengths $(\mathrm{m})$ and $\left(K_{V} / K_{h}\right)$ the anisotropy of the hydraulic conductivity within the system.

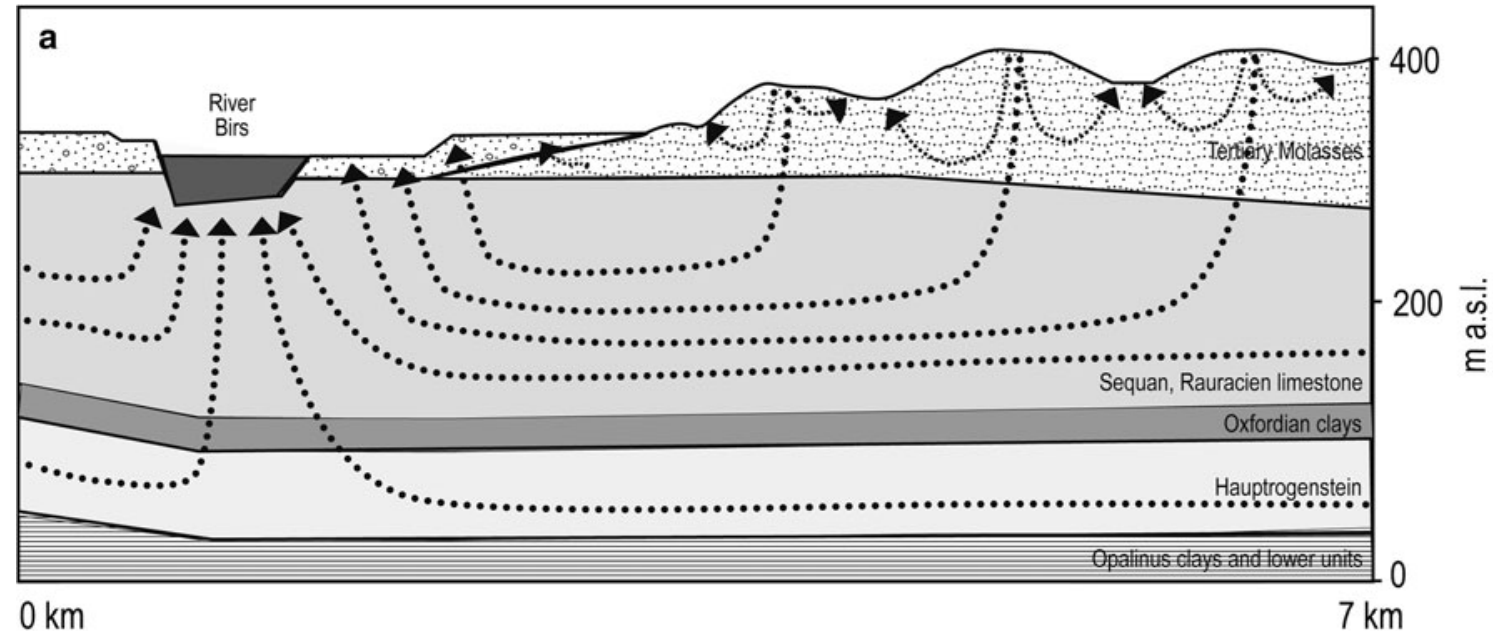

b

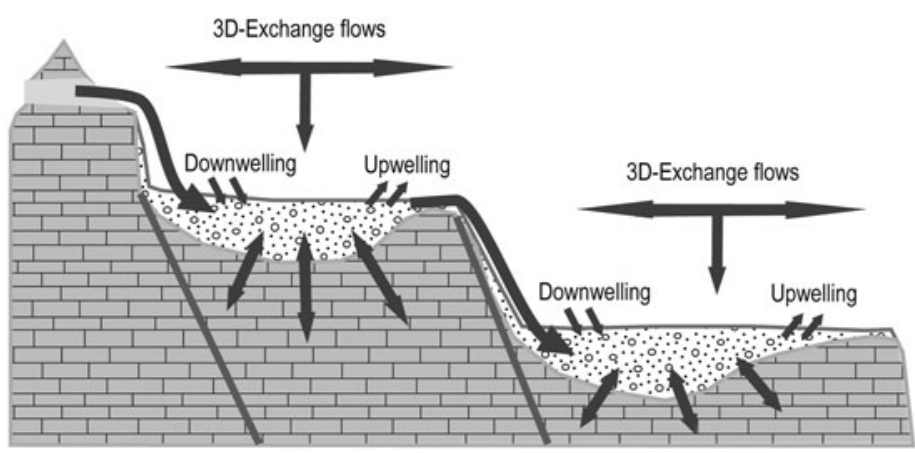

C

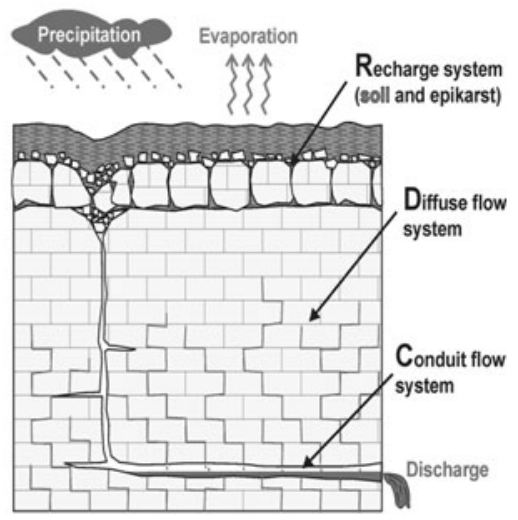

Fig. 3 Conceptual models: a Flow systems and interactions (the figure integrates information from different profiles, see Fig. 1 and frame in the geological profile of Fig. 2); b Cross-sectional representation of the hyporheic corridor concept (redrawn after
(Stanford and Ward 1993); Surface and interstitial flows and interactions between different groundwater flow systems are represented by arrows; and c Conceptual model of a karst groundwater system (after Butscher and Huggenberger 2009b) 
As a basis for the spectral analysis, elevation data of a DEM (Digital Elevation Model, 2 m-resolution) were extracted along the selected profile lines (Fig. 1) in GIS. The data along the profile lines were then fitted in AQUASIM (Reichert 1998, 1994a) making use of the Fourier decomposition, whereby stepwise 2, 3, 4 and 5 harmonic functions were combined. In a next step, the parameters of the superimposed harmonic functions were fitted to the topography (elevation data along the various profile lines). The minima and maxima of the topography were selected for the fitting.

\section{River-corridor concept}

The second concept, the "river corridor" concept (Stanford and Ward 1993), considers exchange processes between surface waters and groundwater systems, which in turn allows the description of the exchange of solutes. Many alluvial rivers in Central Europe flow in very porous floodplains, while the base of GWBs in river valleys is characterized by complex bedrock topography. Furthermore, sequences of GWBs are often observed, whereby basins filled with unconsolidated gravel deposits are separated by bedrock steps. The bedrock steps ("knick-points"; Stanford and Ward, 1993) formed as a result of differences in erodibility of the local bedrock or geological formations formed by fluvial or faulting activity (Figs. 1, 3). In river reaches upstream of "knickpoints", groundwater is forced out of the aquifer to the surface due to a reduction of the saturated cross-sectional area and a subsurface barrier with lower hydraulic conductivity.

The size of GWBs in the unconsolidated river gravels of the River Birs can be defined by a flow-system analysis (see above) in flow direction and locating bedrock steps separating river reaches of individual GWBs. GWBs typically range between tens and several hundreds of meters in width and hundreds of meters to several kilometers in length.

The construction of the geometries of GWBs along the River Birs and the Laufen Basin is based on a profile along part of the river, showing the topography, the groundwater table and the position of the bedrock surface (Fig. 1). The following data sets were combined for the construction of the profile: (1) elevation of the river bed; (2) interpolated groundwater surface within the fluvial deposits along the River Birs, comprising the information of numerous groundwater observation data; and (3) interpolated bedrock surface for regions overlain by the fluvial deposits along the River Birs, comprising the information of 186 existing borehole data.
Dynamic vulnerability concept and aquifer base gradient approach

Karst aquifers in the Laufen Basin provide a considerable amount of groundwater to the regional flow system but they are also related to smaller sub-catchments of different springs occurring in areas where aquifers and aquitards intersect at the surface. The regional and local systems differ in size, in the length of the flow paths, the storage capacities and the residence times. In particular, smaller scale karst groundwater systems are known for being susceptible to pathogen contamination especially after precipitation events due to point recharge, and rivergroundwater interactions (Affolter et al. 2010; Fleckenstein et al. 2006).

The heterogeneous structure of karst generally leads to slow and fast water responses observed in hydrographs of springs. These responses particularly manifest during and after precipitation events in the catchment area and can be studied for local scale karst systems. Concerning the regional karst systems responses occur at the basin scale and are restricted to low frequency events such as catastrophic flooding.

Accounting for these special permeability characteristics, several methods have been developed (Atkinson 1977; Butscher and Huggenberger 2007; Tarafdar 2011; Hartmann et al. 2012; Jeannin et al. 2012) for different spatial scales to understand vulnerability and hydrograph development related to strong precipitation occasionally occurring in these systems (BWG 2001). Two of these approaches are discussed for the local and regional scale karst systems within the Laufen Basin (Fig. 1), including the "dynamic vulnerability concept" and the "aquifer base gradient approach".

\section{The dynamic vulnerability concept}

The term vulnerability is defined as an intrinsic property of a groundwater system that depends on the sensitivity of that system to human and/or natural impact (Vrba and Zaporozec 1994). There are basically two concepts of groundwater vulnerability: intrinsic and specific vulnerability. Intrinsic vulnerability refers to the natural, geogenic vulnerability without relation to a specific contaminant or contaminant source. In contrast, specific vulnerability considers human activities and the impact of a particular land use. It is related to a specific contaminant or contaminant source (Vrba and Zaporozec 1994).

Because vulnerability strongly depends on the recharge conditions, which are highly time dependent (Brouyère 2004) Butscher and Huggenberger (2009b) introduced and 
defined the Dynamic Vulnerability Index (DVI) as the ratio of the different contributions of flow components to spring discharge. High values of DVI, representing a high proportion of water from preferential (fast) flow systems, indicate that the karst system is highly sensitive to contamination at this point in time. The approach using DVI as an indicator for spring water contamination was tested for a local scale karst system within the northwest of the Laufen Basin (see Fig. 1) by comparing calculated DVI time series with fecal indicator occurrences in a karst spring (Butscher and Huggenberger 2009b).

Over the period of 3 months from October to December 2000 water samples were taken from the investigated spring three to six times per day (Butscher et al. 2011a). The samples were analyzed for the fecal indicators $E$. coli, enterococci, $C$. perfringens, and heterotrophic plate count bacteria in accordance with the Swiss drinking water regulations (SLMB 1987).

Groundwater flow was simulated using the rainfall-discharge (lumped parameter) model RCD (Recharge Conduit Diffuse systems) (Butscher and Huggenberger 2008). In this model, three linear storages represent the flow systems typical of karst aquifers: the recharge system (soil and epikarst system, Perrin et al. 2003), the conduit system and the diffuse flow system. Model input is defined by precipitation and evapotranspiration data. Model output represents the spring discharge. Flow through the system is calculated based on the principle of mass (or water volume) conservation.

Storage volumes are given by the equation:

$\frac{\mathrm{d} V_{\mathrm{S}}}{\mathrm{d} t}=Q_{\mathrm{S}, \text { in }}-Q_{\mathrm{S}, \text { out }}$,

where $V_{\mathrm{S}}$ is the storage volume, $t$ is time, $Q_{\mathrm{S} \text {, in }}$ is the volumetric inflow and $Q_{\mathrm{S} \text {,out }}$ is the volumetric outflow of the storage. Flow through links connecting the storages is given by the equation:

$Q_{\mathrm{L}, \text { out }}=Q_{\mathrm{L}, \text { in }}-\sum Q_{\mathrm{L}, \text { bif }}$,

where $Q_{\mathrm{L}, \text { in }}$ and $Q_{\mathrm{L} \text {,out }}$ are the water inflow from and outflow to the connected storage, and $Q_{\mathrm{L}, \text { bif }}$ is the flow through a bifurcation of the link. Inflow into storage, outflow from storage and flows bifurcating from links are specified by the modeler. All other flows are calculated numerically solving the differential equation noted above.

The model was calibrated inversely by a parameter estimation algorithm, minimizing the sum of the squares of weighted deviations between measured and calculated spring discharge. For details concerning the model formulation and the used numerical algorithms refer to (Butscher and Huggenberger 2008; Reichert 1994a, b). The calibrated model was used to calculate the dynamic vulnerability index DVI, which is defined by:
$\mathrm{DVI}=Q_{\text {out }, \mathrm{C}} / Q_{\text {out }, \mathrm{D}}$

where $Q_{\text {out,C }}$ and $Q_{\text {out,D }}$ is the outflow from the conduit and diffuse flow system, respectively.

\section{The aquifer base gradient approach}

In mature karst systems, such as the regional scale karst aquifer within the Oxfordian limestones of the Laufen Basin, the subsurface flow could be approximated to open surface flow at the aquifer base on top of the aquitard. The regional scale karst aquifer has never been covered by low permeable sediments and has been exposed to the land surface since the end of the Jurassic (Gürler et al. 1987). This explains the high degree of karstification of the system. The gradient of the aquifer base is expected to mainly influence the regional groundwater flow patterns (Butscher and Huggenberger 2007). Although this approach has not been applied to the Laufen Basin yet, it might be useful for the understanding of the flooding mechanisms in case of torrential rainfall events ("The river-corridor of the Laufen Basin”).

\section{Results}

Flow system scales

The results of the spectral flow-system analysis of three representative topographical profiles across the Laufen Basin (Fig. 4, see Fig. 1 for localization of profile traces) and the stepwise combination of 2, 3, 4 and 5 harmonic functions revealed that the topography can be fitted with three major wavelengths (Table 1). These wavelengths correspond to the principal local and regional flow systems.

The delineation of flow systems in the sections parallel and perpendicular to the strike of the main geological structures results in three principal aquifer units: (1) the regional scale aquifer unit, (2) the km-scale "Rhine Graben Molasses" aquifer unit; and (3) the local scale shallow aquifer units within the unconsolidated sediments of the river valleys. Below, the first two aquifer units are described in detail, the third aquifer unit is described in "The river-corridor of the Laufen Basin".

The relation of $K_{V} / K_{h}$ is assumed to be in the order of $10^{-4}$ (Nagra 2002), this means, the hydraulic conductivity of the aquicludes influence the overall vertical hydraulic conductivities, whereas the horizontal K-value is mainly determined by the $K$-values of the aquifers (Table 1). The penetration depth estimates of the different flow systems correspond to the depth expected from the structural analysis (Laubscher 1998). 
Fig. 4 Fourier analysis of the topography in different flow directions forms the basis for the estimation of spatial scales in the water table (profiles 1-3 see Fig. 1) illustrated together with selected scales of flow systems (see Table 1 for selected wavelength/ penetration depth)

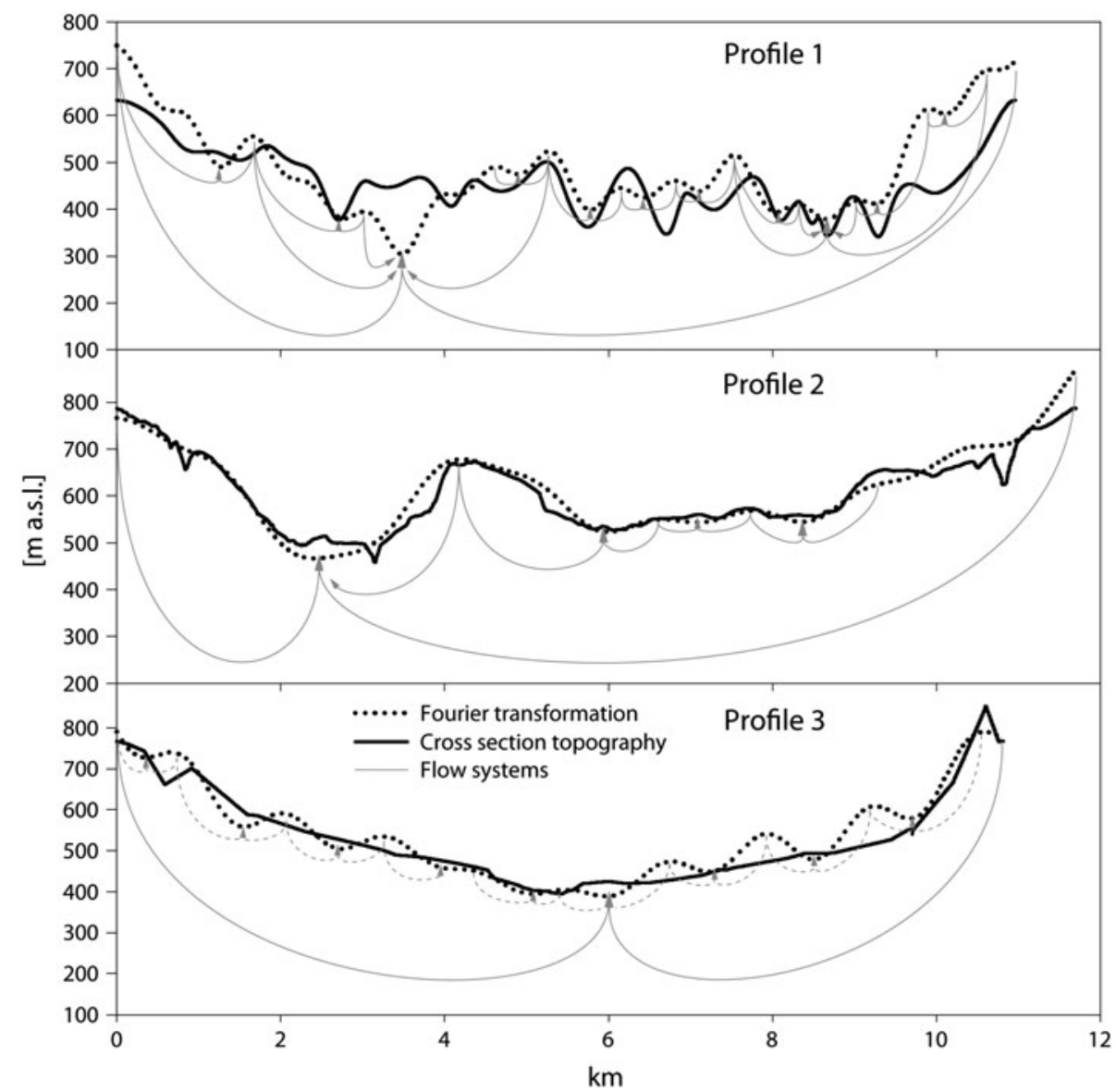

Table 1 Results of the Fourier analysis for profiles 1-3 (see Fig. 1 for locations)

\begin{tabular}{|c|c|c|c|c|c|c|}
\hline & & \multicolumn{5}{|c|}{ Flow system } \\
\hline & & 1 & 2 & 3 & 4 & 5 \\
\hline \multirow[t]{3}{*}{ Profile 1 penetration depth $^{*}(\mathrm{~m})$} & Wavelength & $17^{\prime} 929$ & $6^{\prime} 965$ & $2^{\prime} 720$ & $1^{\prime} 147$ & 740 \\
\hline & Anisotropy 0.005 & $1^{\prime} 268$ & 492 & 192 & 81 & 52 \\
\hline & Anisotropy 0.001 & 179 & 70 & 27 & 11 & 7 \\
\hline \multirow[t]{3}{*}{ Profile 2 penetration depth $^{*}(\mathrm{~m})$} & Wavelength & $23^{\prime} 326$ & $7^{\prime} 183$ & $4^{\prime} 073$ & $2^{\prime} 929$ & $1^{\prime} 285$ \\
\hline & Anisotropy 0.005 & $1^{\prime} 649$ & 508 & 288 & 207 & 91 \\
\hline & Anisotropy 0.001 & 233 & 72 & 41 & 29 & 13 \\
\hline \multirow[t]{2}{*}{ Profile 3 penetration depth ${ }^{*}(\mathrm{~m})$} & Wavelength & $21^{\prime} 057$ & - & - & - & - \\
\hline & Anisotropy 0.001 & 211 & & & & \\
\hline
\end{tabular}

Italic numbers represent the wavelength (penetration depth) of the flow systems which are illustrated schematically in Fig. 4

* penetration depth: $\delta=\lambda\left(K_{V} / K_{h}\right)^{1 / 2}$

Half of wavelength 1 of the three profiles corresponds to the basin diameter. Half of the 2 nd and 3 rd wavelengths of profile 3 reflect the two depressions between two ridges. The 4th and 5th wavelengths of profile 1 may be explained by local-scale topographic features visible in the domain of the Rhine Graben Molasse (Fig. 2). Based on wavelengths and the anisotropy of the different aquifer systems in the order of $10^{-4}$, the penetration depth of the karst and the
Molasse is in the order of $200-230 \mathrm{~m}$ of the top carbonate aquifer and between 10 and $70 \mathrm{~m}$ for the Molasse aquifer.

In the Laufen Basin, the location of the phreatic surface is only known in the alluvial valleys and, for one case only, in part of the karst system (see "Interaction between aquifer units"). Similar to the "Rhine Graben Molasse" system, this sequence is supposed to produce water table controlled systems at the regional scale. However, at the 
geological-formation scale (i.e. the Upper Oxfordian carbonates), rapid responding to strong precipitation events of karst systems is observed. Thus, in this type of system, topography-controlled behaviour seems to be related to low or moderate hydraulic conditions, whereas during high flow, the system's character shifts towards recharge-controlled conditions (see "Discussion").

This approach leads to a simple expression of the penetration depth of a flow system as a function of the system's lateral extension and anisotropy of the subsurface. There are many advantages of using the topography of an area as the top boundary condition for a flow domain. In comparison to precipitation data, elevation data are easily accessible, accurate and have a high resolution (Marklund and Worman 2011). However, this boundary condition is only valid if the water table is an exact replica of the topography. As the water table never follows the topography exactly, applying topography as the boundary condition induces a systematic error in the water flux at the top boundary (Marklund and Worman 2011). The magnitude of this error is dependent on how closely the phreatic water surface follows the topography. One limiting assumption for most of these types of studies is that the location of the groundwater surface is known and static. Haitjema and Mitchell-Bruker (2005) tested the hypothesis of Tóth (1962) and Zijl (1999). Based on an analysis of groundwater rise in regional unconfined aquifers, using both a $2 \mathrm{D}$ boundary element method and a 1D Dupuit-Forchheimer model, they developed criteria for circumstances where groundwater flow is controlled either by topography or by recharge. The criterion considers transmissivity, areal recharge and average saturated aquifer thickness as well as the distance between hydrological boundaries.

\section{The regional scale aquifer unit}

Two stratigraphic units forming the main karst aquifers in the Laufen Basin control the large scale hydrological flow regimes of the studied area. The upper Oxfordian carbonates comprise reef facies with massive limestone and high primary porosity with thicknesses between 40 and $70 \mathrm{~m}$ and above an up-to $110 \mathrm{~m}$ thick Vellerat formation is composed of bedded limestone with varying facies and interbedded marl. The aquifer base is composed by the approx. $100 \mathrm{~m}$ thick Oxfordian marl (Fig. 2). There is no indication of deposits of Cretaceous and early Tertiary ages, thus karstification of the Oxfordian limestone could have already started during early Cretaceous times. According to the hydrogeologic evolutionary typology of karst proposed by (Klimchouk 2009; Ford and Williams 2007), the setting corresponds to an exposed, open karst.

According to Haitjema and Mitchell-Bruker (2005), topography-controlled water tables are expected in such aquifers. At the larger scale, the geological formations are made up of two aquifers, with an aquitard in between (Oxfordian marls) and the Opalinus clay forming an aquiclude below the lower aquifer. The lower aquifer comprises the $50-80 \mathrm{~m}$ thick Bajocien Lower Hauptrogenstein Formation, an oolithic limestone sporadically inter-bedded by marl (Fig. 2). The outcrops of the lower aquifer are restricted to the North and South of the basin.

\section{Km-scale "Rhine Graben Molasse" aquifer unit}

There is only incomplete knowledge of the hydrogeology of the Molasse flow system. However, due to the intense agricultural activities this system is likely to be vulnerable with respect to agricultural chemical compounds. The Oxfordian and the Bajocien lower aquifers in the "Rhine Graben Molasse" are overlain by a max. $200 \mathrm{~m}$ thick sequence of late Oligocene to middle Miocene deposits (Fig. 2). The deposits mainly consist of conglomerates with intercalations of more permeable sand bodies, marls and karstified freshwater carbonates. This sequence corresponds to an anisotropic aquifer of generally low permeability. The extension of the sediments of the "Rhine Graben Molasse" is laterally limited by an area of about $18 \mathrm{~km}^{2}$ in the eastern-central part of the Laufen Basin. The $K$ values vary between $10^{-4} \mathrm{~m} / \mathrm{s}$ (sandstones and conglomerates) to $10^{-8} \mathrm{~m} / \mathrm{s}$ (marls and clays) (Nagra 2002). The hydrogeological system is characterized by a complex near surface groundwater system with components of interflow, rapid increase of discharge following major precipitation events and a system mainly influenced by the topography of the North-South striking ridges draining into the regional surface waters.

\section{The river-corridor of the Laufen Basin}

The Quaternary alluvial sediments within the Laufen Basin were deposited in the main valley of the River Birs on a bedrock surface of mainly Upper Oxfordian karstified Carbonate to Tertiary fluvial deposits (Figs. 2, 3). They consist mainly of fluvial gravels that are up to $30 \mathrm{~m}$ thick which are locally covered by overbank deposits. During deglaciation and Holocene times, a series of river terraces were formed which are separated from each other by terrace bluffs. The geometry of the surface morphology gives some indication on the development of the valley fills. Due to the high permeability and porosities, the fluvial gravel deposits represent the most productive groundwater reservoirs in the area. Pronounced sedimentary structures and textures in the gravel deposits are important for the interpretation of the heterogeneous groundwater flow field and flow regime. 
Figure 1 illustrates a profile with a sequence of groundwater bodies along part of the River Birs. In combination with the information on the progression of fluvial deposits along the River Birs two groundwater bodies can be identified when viewed from above (Fig. 1). The first groundwater body begins at transect $\mathrm{km} 0.8$ and ends at transect $\mathrm{km} \mathrm{1.8.} \mathrm{The} \mathrm{second} \mathrm{groundwater} \mathrm{body} \mathrm{begins} \mathrm{at}$ transect $\mathrm{km} 2$ and ends at transect $\mathrm{km} \mathrm{4.2.} \mathrm{Within} \mathrm{both}$ groundwater bodies, additional bedrock elevations result in local alterations of river-groundwater interaction processes. The second groundwater body is furthermore influenced by an artificial river dam, which results in an impoundment of the river and groundwater upstream of the dam.

Infiltration of river water into groundwater aquifers structured by fluvial outwash materials can reach specific infiltration rates of up to $1 \mathrm{~m}^{3} /$ day per $\mathrm{m}^{2}$ of river bed (Affolter et al. 2010). Losing and gaining reaches of channels are related to so-called 'knick points' or bedrock steps (Stanford and Ward 1993). In the river reach upstream of a knick point, water is forced out of the ground to the surface (Figs. 1, 3). The dynamic nature of rivers complicates the interpretation of surface-groundwater interaction processes (Woessner 1998). Seasonal variation in the height of the water table and channel stage can alter the magnitude, location and direction of exchange (Affolter et al. 2010). Exchange rates are controlled by the difference between the river stage and groundwater head, and the hydraulic conductivity of the riverbed.

\section{Dynamic vulnerability of the local scale karst system}

The field site for the comparison of fecal bacteria occurrence in spring water with calculated DVI is located on the northwestern edge of the Laufen Basin (Fig. 1). Hydrogeological investigations of the karst spring (Lützel Spring) resulted in an estimate of the sub-catchment area in the order of $2.8 \mathrm{~km}^{2}$. The spring has a variable discharge in the range of $800-4,500 \mathrm{l} / \mathrm{min}$. The aquifer is unconfined and comprises Oxfordian limestone composed of patch-reef facies of a shallow carbonate platform (Fig. 5). Based on dye tracer experiments and a morpho-tectonic analysis, surface-connected conduit systems were identified in the catchment (Butscher et al. 2011a). The distance from the entrance of the conduit systems to the spring is $1,250 \mathrm{~m}$. Depending on spring discharge, tracer flow velocities ranged between 40 and $100 \mathrm{~m} / \mathrm{h}$.

The calibration results of the RCD model (Butscher et al. 2011a) are illustrated in Fig. 5, which shows measured and calculated spring discharge, precipitation and evapotranspiration. In a first overview there is good agreement between measured and calculated spring discharge. However, smaller discharge peaks cannot be portrayed and resolved. This might be due to the relatively coarse spatial resolution of the precipitation data, which are based on a single gauging station in the area or due to the simple model structure. Small precipitation events do not always lead to small peaks in discharge (Fig. 5). The calculated DVI, the spring discharge and the comparison with measured spring discharge indicate a correlation between DVI and measured spring discharge. For a period of three months, field samples of spring water were analyzed for fecal indicator microorganisms. For this period, which includes five distinct recharge events, a more detailed analysis is given by Butscher et al. (2011a).

The relationship between the $E$. coli fecal indicator microorganisms and calculated DVI during the five analyzed events is shown in Fig. 5. Generally, there is good correspondence between DVI and the distribution of fecal indicator bacteria. E. coli coincides well with large DVI, with exception of event number four, where only a small number of $E$. coli occurs. An important factor for the design of management schemes and processing of raw water is the time lag between the increase of DVI and the first occurrence of microorganisms. The data indicate that DVI can record the beginning of microbial pollution. However, during event number one, microorganism concentrations start to increase earlier than DVI ( $E$. coli $0.75 \mathrm{~d}$ before), in events 2-5, calculated DVI increases earlier than microorganism concentrations start to increase.

\section{Interaction between aquifer units}

The local aquifer unit under consideration is located in the central western part of the Laufen Basin, just where the Jura fold-belt interacts with the Laufen Basin (Figs. 1, 2). Due to sporadic bacteriological contamination in the untreated water of an extraction well, an observation network and a high-resolution numerical groundwater model were set up (Huggenberger and Scheidler 2008; Butscher et al. 2011b). Depending on the hydrologic boundary conditions, the extracted groundwater is more or less influenced by infiltrating river water, or water with short residence times within the conduit system of the karstified carbonate formations. Prior to the investigations it was assumed that infiltrating river water with short residence times was the major source of the sporadic bacteriological contamination in the untreated water of the extraction well. However, hydrochemical and microbiological signatures, as well as groundwater heads revealed that river-groundwater interaction is not the only process to be considered, but that the shallow valley aquifer interacts with the regional scale karst system as described above (Fig. 6). The change of electrical conductivity measured in two wells coincides to the increase in fecal bacteria concentrations $(E$. coli) in the karst groundwater, whereas no increase of the $E$. coli concentrations was observed in the 


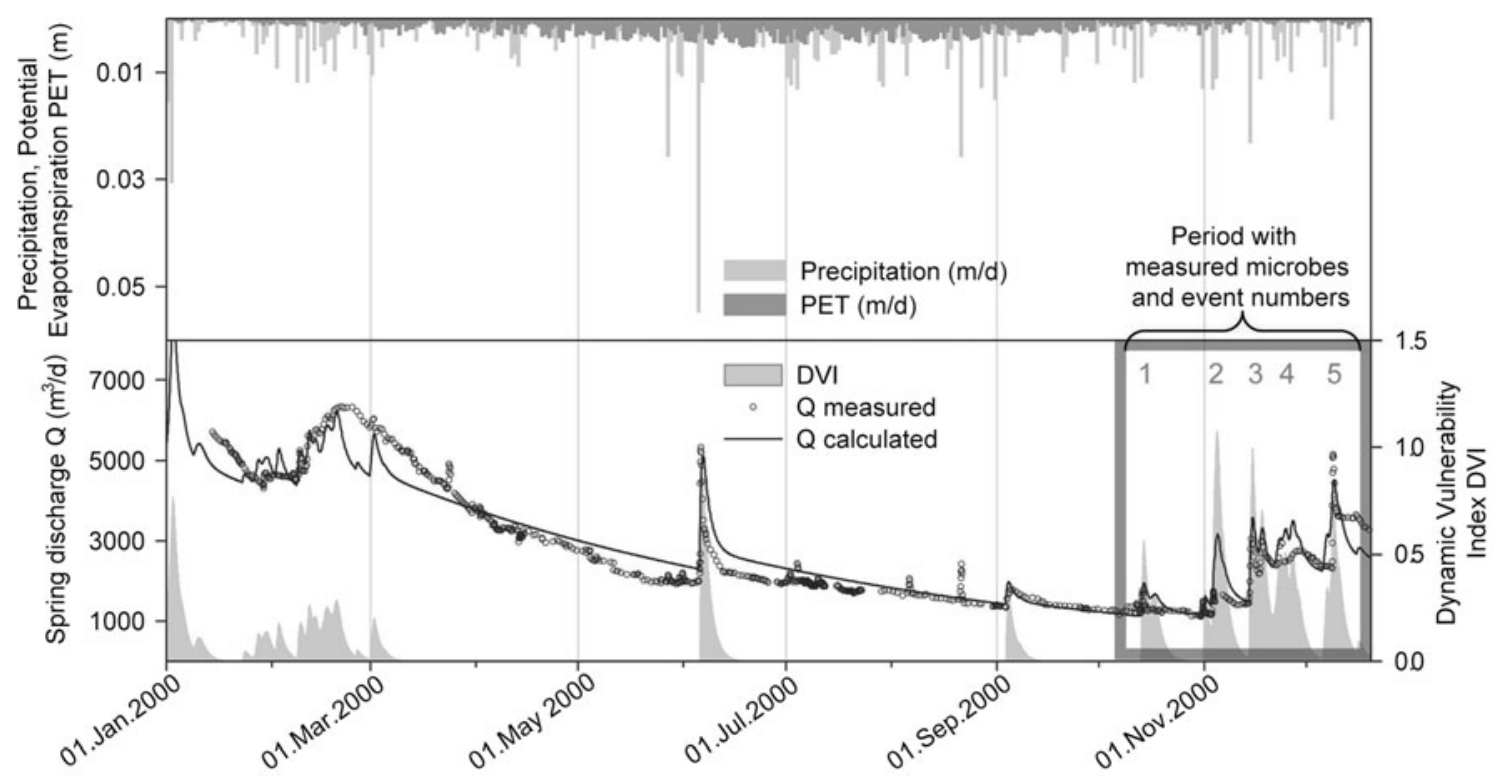

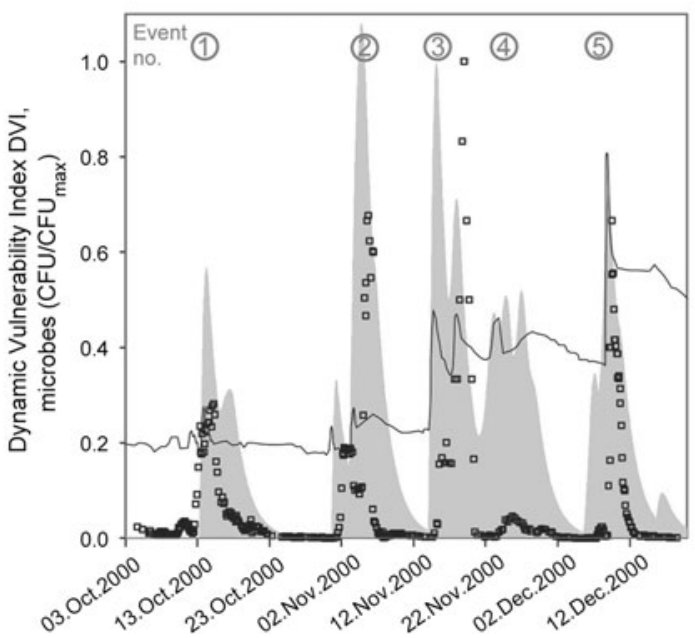

Fig. 5 Top Measured and calculated spring discharge, precipitation, potential evapotranspiration and calculated DVI during the year 2000; Bottom left Detailed representation of E. coli data and DVI from

groundwater of the valley aquifer. An 80-h delay between maximum groundwater level and maximum concentration of aerobic mesophilic germs was observed in the groundwater observation well near the river. In contrast, the observation well connected to the karst aquifer units shows a delay between the two maxima of only 2 days. Although, one would expect a microbiological signal within the groundwater from infiltrating surface water, the data clearly indicate a pronounced influence of karst water on groundwater quality during high flow conditions.

The quantitative aspects of the influence of the regional scale karst aquifer units are illustrated by a large flood event (Müller 2009; Butscher et al. 2011b; Bezzola and Ruf 2009). Precipitation on the 8th of August 2007 in Switzerland was mainly concentrated in several local precipitation cells. A large rain cell was located above in the

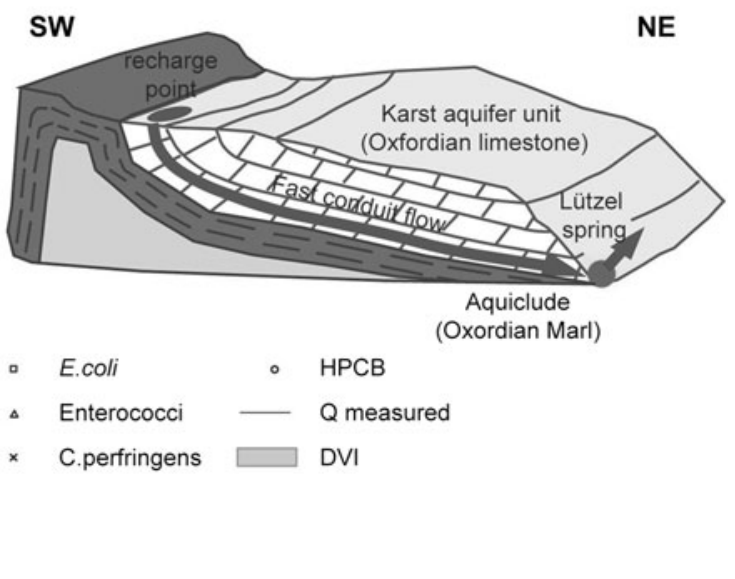

October to December 2000 (part of the frame above). Bottom right Setting of the vulnerability case study in the Birs sub-catchment (see Fig. 1 for location, modified after (Butscher et al. 2011a))

catchments of the rivers Aare and Rhône and a smaller cell was located above the entire catchment of the River Birs (Fig. 7). Within $24 \mathrm{~h}$, precipitation amounted to $100 \mathrm{~mm}$ per $\mathrm{m}^{2}$. The hydrograph of the River Birs (BAFU station Münchenstein, Hofmatt 2106) which initially showed a discharge of about $20 \mathrm{~m}^{3} / \mathrm{s}$ increased by about $190 \mathrm{~m}^{3} / \mathrm{s}$ within the first $6 \mathrm{~h}$ and by about $325 \mathrm{~m}^{3} / \mathrm{s}$ within $17 \mathrm{~h}$. As a consequence, the Laufen Basin was flooded along the River Birs at several river sections, including a major flooding of the city center of Laufen where the groundwater table rapidly rose up to the surface (Fig. 7). This flood event, with a recurrence period in the order of 100-300 years, was attributed to the high discharge of the River Birs. The analyses of the groundwater observation wells in the city clearly show a rapid increase of the groundwater table to a level above the ground surface (Fig. 7). As the sedimentary 
Fig. 6 Top Cross-section showing the interactions between the surface water, the gravelly aquifer of the Birs valley and the karst aquifer unit (see Fig. 1 for locations). Bottom Data set of a flood event in April 2008 illustrating the hydraulics within the different aquifer units, electrical conductivity (EC) measurements and measured microbiological parameters
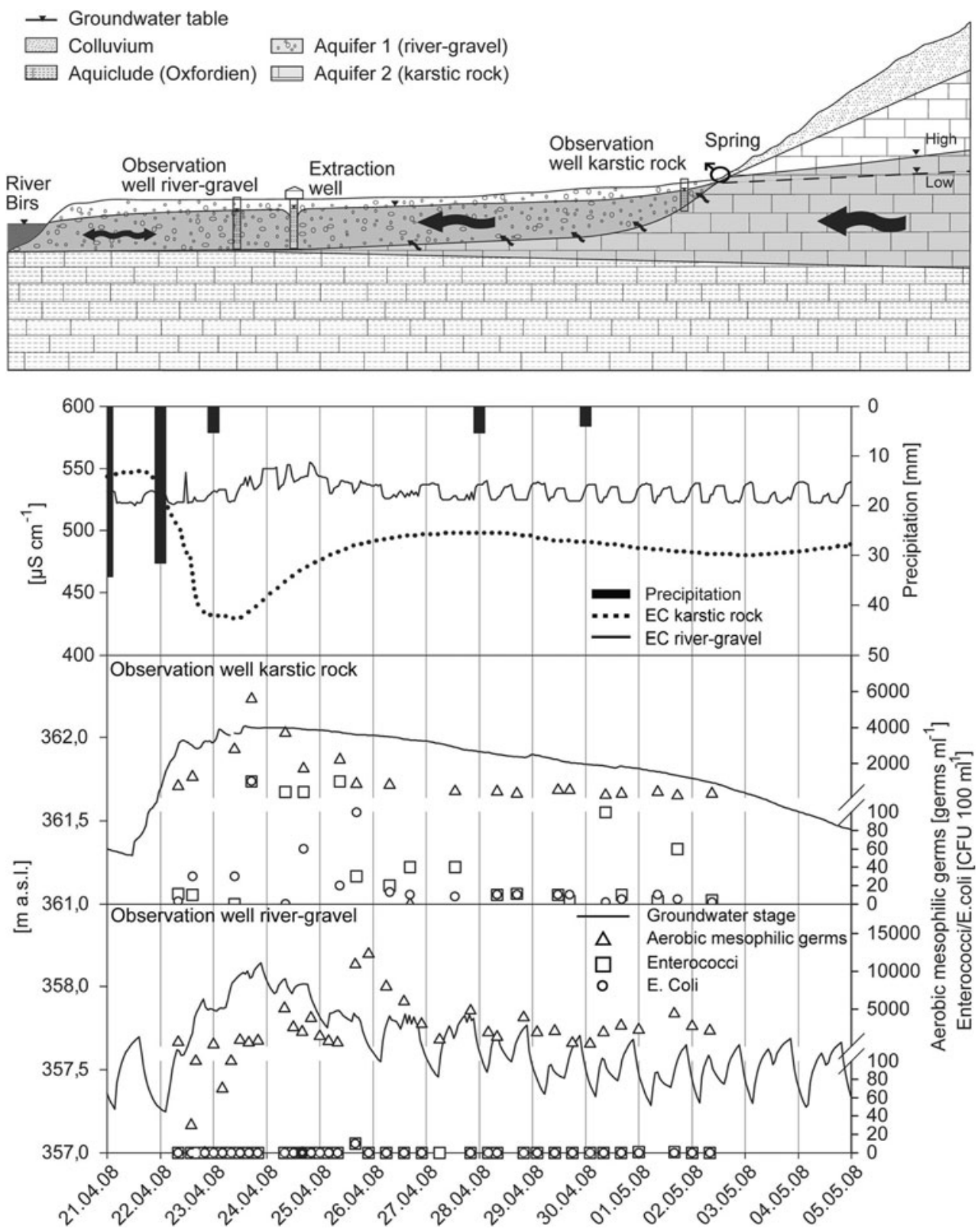

cover (fluvial gravel) in Laufen is thin or lacking, the rapid increase can be explained by a combination of rapid propagation of pressure waves within the regional karst aquifer units, induced by an increase of the hydrostatic pressure of the regional scale karst system and a fast increase in river-groundwater interaction processes where the River Birs enters the Laufen basin (Figs. 1, 3).

\section{Discussion}

In the presented article, a conceptual framework to understand multi-scale groundwater-flow systems is presented.
The approach and the examples illustrate the complex scales of interacting hydrogeological processes. Applying the Water Framework and Flood Directives (CEC 2000) or the requirements set by the Wasser-Agenda (WasserAgenda 2011) would mean increasing the use of sustainable techniques which consider the integrity of complex systems and abandon of the sectorial views, instead considering management of water resources in a broader context of water resource management at the sub-catchment scale. Sectorial view means that different aspects of water or groundwater protection and/or management, i.e. drinking water, ecology or flood protection are treated in different regulations and managed by different 
Fig. 7 Top left Precipitation distribution in Switzerland on the 8th of August 2007 (MeteoSwiss, the Birs catchment area is equal to the zone of about $100 \mathrm{~mm}$ rain within 24 h). Top right Flooding of the town of Laufen (Müller 2009). The dark parts within the water indicate the overflow of oil tanks. Bottom Measured groundwater table at the public bath in Laufen (see Fig. 1 for location)
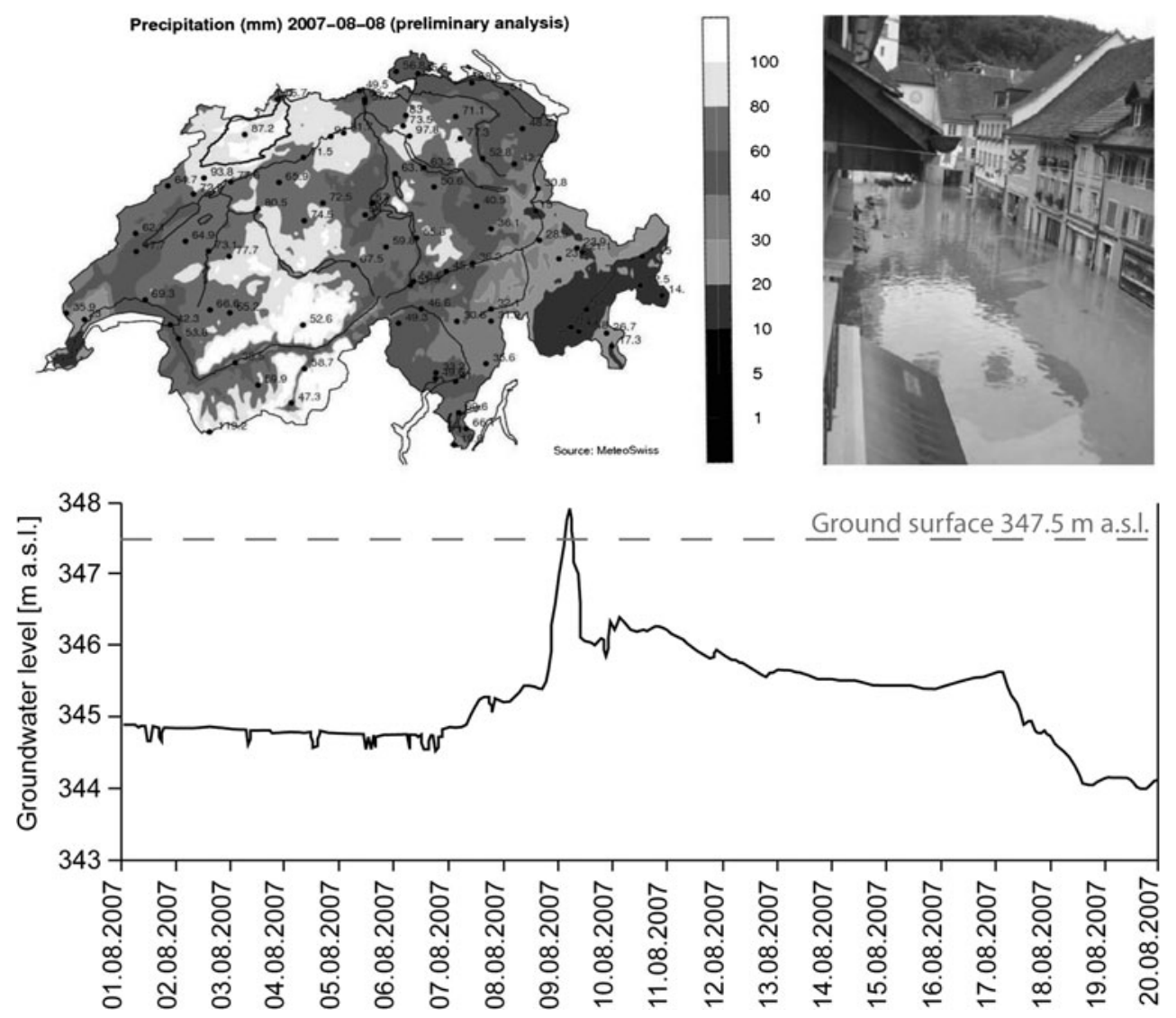

governmental institutions or at different levels such as on federal -, cantonal- or community level.

There is specific groundwater monitoring data available from the Birs valley aquifer. Changes of the microbial quality of the groundwater have been attributed to the influence of infiltrating river water. During the 2007 flood event in the centre of the Laufen Basin rapidly rising groundwater levels (above and below ground) were observed. This shows that beside the high river discharge other processes have to be considered at a regional scale. The 2007 flood event also revived old issues concerning the capture zones of wells in the contact area between the different aquifer units. The revival instigated investigations on the alluvial aquifer and the karst flow systems as well as the aquifers in the Rhine Graben Molasse sediments, which document the strong contribution of karst water to the water balance at high flow conditions. Such interactions had previously not been documented, because of a lack of monitoring data in the different flow systems until the late 1990s. The variety of effects on groundwater quality and quantity in the Laufen Basin during the 2007 flood event became a starting point for a controversial discussion on sustainable management of water resources at the catchment or subcatchment scale considering qualitative aspects alongside flood protection.
Mitigation measures of flood event in the Laufen basin

An illustrative example for the strong interaction between the regional scale system and the alluvial aquifer is the flood event in the town of Laufen in 2007. This event also illustrates the controversy in flood mitigation in the area.

The proposed flood mitigation concept included raising discharge capacities by increasing the width and the depth of the River Birs. An enlargement of the riverbed was refused due to land-ownership issues and lowering of the river bed was preferred for the same reasons. However, lowering of the riverbed is expected to lower the base level of outflow of the Laufen Basin. As a consequence, a change of groundwater storage capacity within the system is expected. A quantification of such changes could be of importance during droughts. Therefore, flood management without considering the dynamics of the regional scale flow system at high flows and of river-groundwater interaction at high and low flow conditions could lead to erroneous conclusions. A lowering of the river bed is likely to decrease the groundwater base level and with it the volume of available groundwater within the groundwater body, especially at low flow conditions. This would be relevant for the water supply of one community.

During the flood event of 2007, all the water supply systems located in the alluvial valley failed partly due to 
inundation of the floodplain and because of a blackout of the power supply for the groundwater pumping stations. This emphasizes the importance of setting up a network of different drinking water production systems, including springs from Molasse and the karst aquifer units. Such mitigation strategies could improve the security of the regional water supplies.

For the investigated sedimentary basin it is recognized that there are time periods where the different aquifer units seem to behave independently; however, the interaction becomes apparent during extreme events, such as high flows or droughts. To conclude, the understanding of the dynamics of the multi-aquifer system for different hydrological conditions, as well as identifying appropriate measures would ensure a sustainable use of the water resources in such areas.

Scale aspects of sub-catchment management approaches

The influence of different scales in space and time for the development of water management systems is discussed. The small scale starts at several square meters in respect to hydrological as well as ecological borders (e.g. habitats, i.e. (Malard et al. 2002), while the large scale $\left(>\mathrm{km}^{2}\right)$ contains the whole or different river sub-catchments. Between these extremes, a range of intermediate steps are located. The hierarchy of these scales was derived based on a Fourier analysis of the topography in the directions parallel and perpendicular to the geologic structures. A useful up- and downscaling requires consideration of three levels of organization: (1) the level in question (e.g. water quality of a river reach); (2) the level below that provides insight into mechanisms or processes (e.g. development of fluxes or water quality); and (3) the level above that provides context and significance (e.g. catchment of the river).

Investigating interactions between surface water and groundwater and groundwater-dependent ecosystems is a primary need in determining the magnitude and range of exchange processes of multi-aquifer systems. The interaction between surface and groundwater systems depends on the natural variability of system input (recharge) within the different aquifer units. Anthropogenic impacts and climate change overprint the natural variability of these system inputs (Epting and Huggenberger submitted-b). In the subsurface, the boundary conditions, such as the exchange of water between different aquifer units, are often nonstationary. Non-stationarity increases, particularly when groundwater interacts with rivers or when aquifer parameters are not uniformly distributed as in karst aquifer units (Epting et al. 2011). As these relations are poorly understood, specific monitoring systems are required to increase our knowledge on exchange processes between different aquifers and the surface waters.
Requirements for monitoring networks

Our results clearly show that the existing monitoring network only allows an incomplete understanding of the dynamics and the interaction of the different flow systems in the Laufen basin. A revision of the present monitoring system and an adaption of the groundwater observation networks for monitoring hydraulic, physical and chemical parameters is the basis for the development of a subcatchment or catchment-scale water-management systems.

Important questions that need to be asked to help optimizing observation networks include: Where are data gaps, which parameters are reasonable to be measured, which data can be used as indicators and/or proxies for specific processes? How can measurements on different temporal and spatial scales optimally be combined? How can boundary conditions be specified? How can observation networks be optimized, with respect to uncertainty in the quantity to be assessed for given costs. Other aspects, such as installation, communication, and automatic data storage and data retrieval become important factors when installing observation networks?

Parameter monitoring and data collection are an essential part of understanding processes in groundwater systems (Rink et al. 2012). As an illustration, due to the existence of slow groundwater flow-systems of the Rhine Graben Molasse in the Laufen Basin, the memory effect of agrochemicals used in the area is expected to be different in the Molasse groundwater compared to the alluvial valley aquifer. Thus, the long-term trends of the memory effect of agrochemicals in groundwater cannot be observed in the alluvial aquifer. In particular, the development of a measured parameter over time is dependent on the dynamics of the system. Small, yet steady changes can easily go undetected. They can, however, give us information on the system dynamics and allow some conclusions about future development. The time scales at which these systemdynamic-driven changes occur depend on the processes giving rise to the change (Page and Simovic Rota 2011).

\section{Infrastructure development}

Valleys not only are used by surface waters, but mainly by traffic lines, villages, and infrastructure. E.g. currently in the Laufen Basin tunnel roads are planned. Infrastructure such as tunnels can affect groundwater systems during the construction period and after completion (Epting et al. 2007). As a result, subsurface resources are subject to ongoing adaptations under changing hydrological and technical boundary conditions. Often infrastructure development and associated changes in land-use largely takes the pragmatic form of engineering for short-term benefits. New subsurface infrastructure often is realized under 
difficult geotechnical and hydrogeological conditions. In particular, tunnel construction in non-consolidated or karstified rocks and below the water table can lead to a higher risk of surface subsidence or collapse. In some cases, changes in water fluxes and new created water ways can have negative impacts on water systems. The data from observation networks then can be incorporated into models to derive scenarios of the development of quality and quantity of subsurface and groundwater resources.

\section{Process understanding (changing boundary conditions)}

Due to the importance of surface waters for the alluvial valley aquifer recharge, the interaction with the regional scale karst systems and the strong non-stationarity of such systems, efforts for monitoring and modeling these interactions are essential. Especially during periods of increasing surface water temperatures, infiltration rates can rise significantly (more than $50 \%$, e.g. Braga et al. 2007) due to changes in viscosity. In karst systems, the vulnerability with respect to fast pathways or diffuse flow is expected to change too (Butscher and Huggenberger 2009a). However, the direction of change depends on the character of the specific system and can thus not be evaluated based on simple vulnerability analysis.

Global warming due to the greenhouse effect is predicted to cause changes in precipitation patterns and evapotranspiration (IPCC 2007). According to climate change forecasts, precipitation will shift to the winter half-year in the area considered (OcCC\&ProClim 2007). Climate change will have a significant impact on the hydrologic cycle, creating changes in groundwater resources, land cover and riverine ecosystems (SCNAT 2008). This shift results in elevated groundwater recharge, as winter-evapotranspiration losses are less pronounced than the losses in the summer (OcCC\&ProClim 2007). However, during the summer months and within gravel aquifers, less groundwater recharge will occur by the infiltration of river water due to more pronounced dry periods and reduced river discharges. The application of environmental change scenarios to particular areas, such as the Laufen Basin, requires a better understanding of multi-scale water systems.

According to the climate scenarios, the frequency of extreme events will increase in the considered area (CH2011 2011). How to mitigate future flood events at the sub-catchment scale? A careful morphological-sedimentological analysis of flood patterns in the alluvial valleys, especially the pattern developing during the transition from high to low flow conditions would be basic information to plan the diversion of a flood wave out of the inundated part of the floodplain as fast as possible. However, due to the fact that the groundwater table comes to the surface in the city of Laufen, flooding related to extraordinary precipitations cannot be entirely prevented in the "Laufen Basin".

Contrary to flood events, a mayor drought was observed in 2003 in large parts of Europe. In the Birs sub-catchment "Laufen Basin" the riverbed dried out in some river reaches. Upwelling zones were some of the places where aquatic fauna could survive, not only due to the fact of the existence of water, but also due to the lower water temperatures (SCNAT 2008). The discharge of most of the karst springs declined to a level that forced some of the communities to connect their water supply system with communities that produced their drinking water from Quaternary fills of the Birs valley. Therefore, droughts have been the starting point for plans of regional-scale water management. However, realization of such planning is time consuming due to societal reason barriers (decision procedures, land ownership, preservation of beauty-spots).

\section{Conclusions}

Conceptual models of flow systems at the catchment scale allow integrating the description of processes at different scales and are a solid basis for the set-up of appropriate monitoring systems and process models that allow to link different spatiotemporal scales. Defining the geometry and the scales of different aquifer units interacting with the surface waters crossing a sedimentary basin gives an idea of the complexity of relatively small sub-catchment or catchments with respect to the sustainable use of water. Specific examples of groundwater quality and flood-hazard aspects can only be understood in the context of the flow systems.

The delineation of multiple flow systems in sub-catchments requires a good knowledge of the 3D geology and hydrogeology of groundwater systems. Understanding the interaction of surface water and different aquifer units requires a strategy that integrates different approaches. Each of the three concepts has already been successfully tested individually in hydrogeological systems. The principal concepts are: (1) flow-system analysis (Zijl 1999; Tóth 1962); (2) the river corridor concept for understanding aquifer-surface water interaction processes (Stanford and Ward 1993); and (3) the aquifer base gradient approach (Butscher and Huggenberger 2007) and the calculation of the dynamic vulnerability index in karst flow or fractured flow systems (Butscher and Huggenberger 2009b).

Testing such concepts is not only relevant for the optimization of water resource management; it also would allow a process-oriented definition of boundaries and to derive fluxes of water and different compounds across boundaries, which are practically unknown at the moment. 
These boundary fluxes are critical issues for drinking water production systems or flood-hazard analysis.

In many catchment areas, large amounts of geological, hydrological and geotechnical data are available. However, there is a lack of concepts that allow collecting data based on a specific monitoring system, a systematic data analysis that enables characterization of multi-scale aquifer systems and the interaction between the different systems.

Acknowledgments The authors would like to thank Rebecca Page for language editing the manuscript and two anonymous reviewers for their constructive criticism.

\section{References}

Affolter A, Huggenberger P, Scheidler S, Epting J (2010) Adaptive groundwater management in urban areas, effect of surface watergroundwater interaction using the example of artificial groundwater recharge and in- and exfiltration of the river Birs (Switzerland). Grundwasser 15(3):147-161. doi:10.1007/s00767010-0145-6

Atkinson TC (1977) Diffuse flow and conduit flow in limestone terrain in Mendip Hills, Somerset (Great-Britain). J Hydrol 35(1-2):93-110

BAFU (2012) Anpassung an den Klimawandel in der Schweiz: Ziele, Herausforderungen und Handlungsfelder. Erster Teil der Strategie des Bundesrates vom 2. März 2012

Bencala KE (1993) A perspective on stream-catchment connections. J N Am Benthol Soc 12(1):44-47

Bezzola GR, Ruf W (2009) Ereignisanalyse Hochwasser August 2007. Analyse der Meteo- und Abflussvorhersagen; vertiefte Analyse der Hochwasserregulierung der Jurarandgewässer. Umwelt-Wissen Nr. 0927. Bundesamt für Umwelt, Bern

Bitterli-Brunner P, Fischer HR (1988) Erläuterungen zum Geologischen Atlas der Schweiz, Bl. 1067 Arlesheim, Landeshydrologie und -geologie

Braga A, Horst M, Traver RG (2007) Temperature effects on the infiltration rate through an infiltration basin BMP. J Irrig Drain E-Asce 133(6):593-601. doi:10.1061/(Asce)0733-9437(2007)133: $6(593)$

Brouyère S (2004) A quantitative point of view of the concept of vulnerability. Vulnerability and risk mapping for the protection of carbonate (Karst) Aquifers, COST Action 620, Final Report. European Commission, Directorat-General XII Science, Research and Development, Brussels

Butscher C, Huggenberger P (2007) Implications for karst hydrology from 3D geological modeling using the aquifer base gradient approach. J Hydrol 342(1-2):184-198. doi:10.1016/j.jhydrol. 2007.05.025

Butscher C, Huggenberger P (2008) Intrinsic vulnerability assessment in karst areas: a numerical modeling approach. Water Resourc Res 44(3). doi:10.1029/2007wr006277

Butscher C, Huggenberger P (2009a) Enhanced vulnerability assessment in karst areas by combining mapping with modeling approaches. Sci Total Environ 407(3):1153-1163. doi:10.1016/ j.scitotenv.2008.09.033

Butscher C, Huggenberger P (2009b) Modeling the temporal variability of Karst groundwater vulnerability, with implications for climate change. Environ Sci Technol 43(6):1665-1669. doi: 10.1021/es801613g

Butscher C, Auckenthaler A, Scheidler S, Huggenberger P (2011a) Validation of a numerical indicator of microbial contamination for Karst springs. Ground Water 49(1):66-76. doi:10.1111/ j.1745-6584.2010.00687.x

Butscher C, Huggenberger P, Scheidler S, Affolter A, Epting J (2011b) Vulnerability and quality control systems. In: Huggenberger P, Epting J (eds) Urban geology-process-oriented concept for adaptive and integrated resource management. Springer, Basel. doi:10.1007/978-3-0348-0185-0

BWG (2001) Hydrogeologisches Jahrbuch der Schweiz 2000 HJB2000-D. Bundesamt für Wasser und Geologie, p 440

CotEC CEC (2000) Directive of the European parliament and of the council establishing a framework for community action in the field of water policy: joint text approved by the Conciliation Committee. 1997/0067(COD). C5-0347/00

CH2011 (2011) Swiss climate change scenarios CH2011. ISBN: 978-3-033-03065-7

Chatterjee R, Gupta BK, Mohiddin SK, Singh PN, Shekhar S, Purohit R (2009) Dynamic groundwater resources of National Capital Territory, Delhi: assessment, development and management options. Environ Earth Sci 59(3):669-686. doi:10.1007/s12665009-0064-y

Epting J, Händel F, Huggenberger P (re-submitted-a) Development of tools for the thermal management of an unconsolidated shallow urban groundwater body. HESS-D

Epting J, Huggenberger P (to be re-submitted-b) Unraveling the heat island effect observed in urban groundwater bodies. J Hydrol

Epting J, Regli C, Huggenberger P (2007) Groundwater protection in urban areas incorporating adaptive groundwater monitoring and management-reconciliation of water engineering measures along rivers. In: Wostl CP, Kabat P, Moltgen J (eds) International conference on adaptive and integrative water management, Basel, SWITZERLAND, Nov 12-15 2007. Springer, Berlin, pp 97-123

Epting J, Huggenberger P, Zechner E, Gechter D, Zidane A, Konz M, Romanov D (2011) Karst in Urban Areas. In: Huggenberger P, Epting J (eds) Urban geology-process-oriented concept for adaptive and integrated resource management. Springer, Basel. doi:10.1007/978-3-0348-0185-0

Fleckenstein JH, Niswonger RG, Fogg GE (2006) River-aquifer interactions, geologic heterogeneity, and low-flow management. Ground Water 44(6):837-852. doi:10.1111/j.1745-6584.2006. 00190.x

Ford DC, Williams PW (2007) Karst hydrogeology and geomorphology. Wiley, Chichester

Ghasemizadeh M, Schirmer M (2012) Subsurface flow contribution in the hydrological cycle: Lessons learned and challenges ahead-a review. Environ Earth Sci (this issue)

Grathwohl P, Ruegner H, Wöhling T (2012) Catchments as reactors: a comprehensive approach for water fluxes and solute turn-over. Environ Earth Sci (this issue)

Gürler G, Hauber L, Schwander M (1987) Die Geologie der Umgebung von Basel. Beiträge zur Geologischen Karte der Schweiz, Landeshydrologie und -geologie, 160

Haitjema HM, Mitchell-Bruker S (2005) Are water tables a subdued replica of the topography? Ground Water 43(6):781-786. doi: 10.1111/j.1745-6584.2005.00090.x

Hartmann A, Kralik M, Humer F, Lange J, Weiler M (2012) Identification of a karst system's intrinsic hydrodynamic parameters: upscaling from single springs to the whole aquifer. Environ Earth Sci 65(8):2377-2389. doi:10.1007/s12665-0111033-9

Huggenberger P, Scheidler S (2008) Überprüfung der Gewässerschutzzone "Birshalden" Phase II, Errichtung MessstellennetzRoutine- und Ereignisuntersuchung. GPI, Universität Basel

IPCC (2007) Climate change 2007: synthesis report. IPCC, Geneva Jeannin P-Y, Eichenberger U, Sinreich M, Vouillamoz J, Malard A, Weber E (2012) KARSYS: a pragmatic approach to karst 
hydrogeological system conceptualisation. Assessment of groundwater reserves and resources in Switzerland. Environ Earth Sci. doi: 10.1007/s12665-012-1983-6

Kalbacher T, Delfs JO, Shao HB, Wang WQ, Walther M, Samaniego L, Schneider C, Kumar R, Musolff A, Centler F, Sun F, Hildebrandt A, Liedl R, Borchardt D, Krebs P, Kolditz O (2012) The IWAS-ToolBox: software coupling for an integrated water resources management. Environ Earth Sci 65(5):1367-1380. doi: 10.1007/s12665-011-1270-y

Klimchouk A (2009) Morphogenesis of hypogenic caves. Geomorphology 106(1-2):100-117. doi:10.1016/j.geomorph.2008.09.013

Koch K (1923) Geologische Beschreibung des Beckens von Laufen im Berner Jura. Beitr Geol Karte Schweiz, [NF] 48(2):70

Laubscher H (1998) The complex encounter of Rhine graben and Jura at the eastern margin of the Laufen Basin. Eclogae Geol Helv 91(2):275-291

Liniger H (1925) Geologie des Delsberger Beckens und der Umgebung von Movilier. Beitr Geol Karte Schweiz [NF] 55(4):289-303

Malard F, Tockner K, Dole-Olivier MJ, Ward JV (2002) A landscape perspective of surface-subsurface hydrological exchanges in river corridors. Freshw Biol 47(4):621-640

Marklund L, Worman A (2011) The use of spectral analysis-based exact solutions to characterize topography-controlled groundwater flow. Hydrogeol J 19(8):1531-1543. doi:10.1007/s10040011-0768-4

Maxwell RM, Kollet SJ (2008) Interdependence of groundwater dynamics and land-energy feedbacks under climate change. Nat Geosci 1(10):665-669. doi:10.1038/Ngeo315

Müller M (2009) Bericht vom 22.01.2009 über das Hochwasser vom 8./9. August 2007. Kanton Basel-Landschaft, Kantonaler Krisenstab

Nagra (2002) Project opalinuston: syntheses of geoscientific investigation results. vol NTB: 02-03

OcCC\&ProClim (2007) Klimaänderung und die Schweiz 2050. Erwartete Auswirkungen auf Umwelt, Gesellschaft und Wirtschaft

Page RM, Simovic Rota J (2011) Statistical analysis of monitoring data. In: Huggenberger P, Epting J (eds) Urban geology. Springer, Berlin

Perrin K, Jeannin PY, Zwahlen F (2003) Epikarst storage in a karst aquifer: a conceptual model based on isotopic data, Milandre test site, Switzerland. J Hydrolgy 279(1-4):106-124. doi:10.1016/ S0022-1694(03)00171-9

Picot L, Becker D, Cavin L, Pirkenseer C, Lapaire F, Rauber G, Hochuli PA, Spezzaferri S, Berger JP (2008) Sedimentology and paleontology of Rupelian coast paleoenvironments in the Swiss Jura Molasse. Swiss J Geosci 101(2):483-513. doi:10.1007/ s00015-008-1275-z

Poole GC (2002) Fluvial landscape ecology: addressing uniqueness within the river discontinuum. Freshw Biol 47(4):641-660

Reichert P (1994a) Aquasim - a tool for simulation and data-analysis of aquatic systems. Water Sci Technol 30(2):21-30
Reichert P (1994b) Concepts underlying a computer program for the identification and simulation of aquatic systems. Swiss Federal Institute for Environmental Science and Technology (EAWAG), Dübendorf

Reichert P (1998) AQUASIM 2.0-user manual. Computer program for the identification and simulation of aquatic systems. EAWAG Dübendorf

Rink K, Fischer T, Selle B, Kolditz O (2012) A data exploration framework for validation and setup of hydrological models. Environ Earth Sci (this issue). doi:10.1007/s12665-012-2030-3

SCNAT (2008) Biodiversität und Klima-Konflikte und Synergien im Massnahmenbereich, Akademie der Natruwisenschaften

Seward P, Xu YX, Brendonck L (2006) Sustainable groundwater use, the capture principle, and adaptive management. Water SA 32(4):473-482

Stanford JA, Ward JV (1993) An ecosystem perspective of alluvial rivers-connectivity and the hyporheic corridor. J N Am Benthol Soc 12(1):48-60

Tarafdar S (2011) Understanding the dynamics of high and low spring flow: a key to managing the water resources in a small urbanized hillslope of Lesser Himalaya, India. Environ Earth Sci. doi: 10.1007/s12665-011-1493-y

Tóth J (1962) A theory of groundwater motion in small drainage basins in Central Alberta, Canada. J Geophys Res 67:4375-4387

Tóth J (1963a) A theoretical analysis of groundwater flow in small drainage basins. JGR 68(16):4795

Tóth J (1963b) Two-dimensional isotropic flow model showing the distribution of local, intermediate, and regional groundwater flow systems. JGR 68:4795-4812

Tóth J (1995) Hydraulic continuity in large sedimentary basins. Hydrogeol J 3(4):4-16. doi:10.1007/s100400050250

Tóth J (2009) Gravitational systems of groundwater flow, theory, evaluation, utilization. Cambridge University Press, Cambridge

Vrba J, Zaporozec A (1994) Guidebook on mapping groundwater vulnerability, vol 16. IAH International Contributions to Hydrogeology. Heise, Hannover/FRG

Wasser-Agenda (2011) Einzugsgebietsmanagement, Leitbild für die integrale Bewirtschaftung des Wassers in der Schweiz. http:// www.wa21.ch, Bern

Wiering M, Immink I (2006) When water management meets spatial planning: a policy-arrangements perspective. Environ Plann C 24(3):423-438. doi:10.1068/C0417j

Woessner WW (1998) Changing views of stream-groundwater interaction. 1-6 St. Paul, Minnesota

Worman A, Packman AI, Marklund L, Harvey JW, Stone SH (2007) Fractal topography and subsurface water flows from fluvial bedforms to the continental shield. Geophys Res Lett 34(7). doi: $10.1029 / 2007 \mathrm{~g} 1029426$

Zijl W (1999) Scale aspects of groundwater flow and transport systems. Hydrogeol J 7(1):139-150 